\title{
Microbiological Evaluation of Water and Fillets in the Production Chain of Nile Tilapia (Oreochromis niloticus)
}

Gabriel Marcos Domingues de Souza ${ }^{1}$, Lucienne Garcia Pretto-Giordano², Gislayne Trindade Vilas-Bôas ${ }^{1}$, Túlio Oliveira de Carvalho ${ }^{3}$, Ângela Teresa Silva-Souza ${ }^{4,5}$, Mauro Caetano Filho $^{5}$, Ronaldos Tamanini ${ }^{2}$ and Laurival Antônio Vilas-Boas ${ }^{1}$

${ }^{1}$ Departamento de Biologia Geral, Universidade Estadual de Londrina, CP 10.011, CEP 86057.970, Londrina/PR, Brazil

${ }^{2}$ Departamento de Medicina Veterinária Preventiva, Universidade Estadual de Londrina, CP 10.011, CEP 86057.970, Londrina/PR, Brazil

${ }^{3}$ Departamento de Matemática, Universidade Estadual de Londrina, CP 10.011, CEP 86057.970, Londrina/PR, Brazil

${ }^{4}$ Programa de Pós-graduação em Ciências Biológicas, Universidade Estadual de Londrina, CP 10.011, CEP 86057.970, Londrina/PR, Brazil

${ }^{5}$ Departamento de Biologia Animal e Vegetal, Universidade Estadual de Londrina, CP 10.011, CEP 86057.970, Londrina/PR, Brazil

\begin{abstract}
This study evaluated the quantity of total aerobic bacteria, total coliform and Escherichia coli in samples of the Nile tilapia fillet (Oreochromis niloticus) and in water samples at different stages of a tilapia production chain in Brazil. Furthermore, the effect of temperature on the number of such bacterial groups in the fillet and water samples, and the impact of the type of tank, net cages or ponds, during the fattening stage of tilapia on bacterial quantification was ascertained. A generalized linear model with negative binomial distribution was used, aiming to assess the influence of predictor variables like climate season and type of tank, with interaction term, on bacterial counts. Analysis of the results showed that, for water samples, the highest scores of all bacterial groups evaluated were obtained at debugging stage. Additionally, the increase in temperature positively influenced the counting of bacteria, both in water and in fillet samples. Moreover, microbial quantification in fillet samples did not only result from the bacteria present in the animal growth water sites, but also from intrinsic factors involved in the slaughter and filleting processes. In relation to the type of tank, $E C$ and $A B$ counts were significantly lower in net cages than in ponds. In conclusion, the results of this study indicate the need for deployment of additional care, especially at debugging stage, aiming to obtain safer fillets for consumption. Furthermore, in the event of increased temperature, greater attention should be given to the slaughter and filleting processes.
\end{abstract}

Keywords: Water quality; Coliform and aerobic bacteria; Fillets quality aerobic bacteria; Total coliform; Escherichia coli

\section{Introduction}

Fish is considered an important source of protein for humans. Consequently, an increase in consumption, with the resulting increase in the demand for fishes has been occurring worldwide. Thus, fish farming has been increasing in several regions worldwide [1,2] including Brazil, where it has had an intense development in recent years due to various factors, such as climatic and hydrographic conditions favorable for this activity [3]. Brazil produces different species of fish. Among the most frequently cultivated is the Nile tilapia (Oreochromis niloticus-Linnaeus, 1758), which has a faster growth rate, tolerance to harsh environmental conditions and ease of culture techniques [4].

The fish quality is influenced by several factors. Water quality in the different production stages deserves special attention in intensive systems $[5,6]$ as they have high population density where fish are unable to reach sites with better water quality. The monitoring of water quality can be done by measuring physical, chemical and biological parameters. However, special attention should be given to assessing the microbiological quality of the water, which should be monitored by both research and quantification of bacterial indicators of environmental contamination.

Several studies have been conducted to monitor the microbiological quality of water in fish cultures [7-9]. These studies have been performed using mainly Gram-negative bacteria belonging to the Enterobacteriaceae family, represented especially by facultative anaerobic bacteria, which are components of the intestinal microbiota of humans and warm-blooded animals. Some of these are associated with human diseases $[10,11]$ especially the group of total coliforms (TC) and fecal coliforms (FC) [12].

These microbial groups have also been monitored in samples of processed fish, and it has often been shown that the microbiota present in fish is influenced by the microbiota of the aquatic environment $[4,13,14]$. However, to assess the microbiological quality of water and fish, most studies concentrate only on the animal fattening stage, not evaluating other important stages of the production chain, such as the production of fingerlings, juveniles, or debugging and slaughter stages. To fill in these gaps, this study was also conducted to evaluate the microbiological quality of the tilapia fillet, as well as of the water at the different stages of the tilapia production chain in the northern region of Paraná State, Brazil. Finally, this study evaluated the influence of the tilapia culture system in cages and ponds, as well as the potential effect of temperature on the amount of mesophilic aerobic bacteria (AB), total coliform (TC) and Escherichia coli (EC) in water samples and fillets.

*Corresponding author: Laurival Antônio Vilas-Boas, Departamento de Biologia Geral, CCB, Universidade Estadual de Londrina, CP 10.011, CEP 86057.970 Londrina/PR, Brazil, Tel: 55 (43) 3371-4417; Fax: 55 (43) 3371-4191; E-mail: lavboas@uel.br

Received March 21, 2015; Accepted April 10, 2015; Published May 20, 2015

Citation: Souza GMDD, Pretto-Giordano LG, Vilas-Bôas GT, Carvalho TOD Silva-Souza AT, et al. (2015) Microbiological Evaluation of Water and Fillets in the Production Chain of Nile Tilapia (Oreochromis niloticus). J Aquac Res Development 6: 344. doi:10.4172/2155-9546.1000344

Copyright: ( 2015 Souza GMDD, et al. This is an open-access article distributed under the terms of the Creative Commons Attribution License, which permits unrestricted use, distribution, and reproduction in any medium, provided the original author and source are credited. 
Citation: Souza GMDD, Pretto-Giordano LG, Vilas-Bôas GT, Carvalho TOD, Silva-Souza AT, et al. (2015) Microbiological Evaluation of Water and Fillets in the Production Chain of Nile Tilapia (Oreochromis niloticus) J Aquac Res Development 6: 344. doi:10.4172/2155-9546.1000344

Page 2 of 6

\section{Materials and Methods}

\section{Study area}

Five fish farming that comprise the Nile tilapia (O. niloticus) production chain in northern Paraná State, Brazil, were assessed for evaluation of microbiological quality of both water and produced fillets. This chain was composed of a single property responsible for the production and supply of larvae and pre-juveniles (animals up to $5 \mathrm{~g}$ ) to all other properties. Among those are five properties with tanks for fish at the juvenile (animals up to $10 \mathrm{~g}$ ), intermediate (animals up to $100 \mathrm{~g}$ ) and fattening stages (animals with approximately $500 \mathrm{~g}$ ), which three properties had ponds, while two properties had floating net cages systems located on the Tibagi and Paranapanema basins, respectively. The debugging, slaughter and filleting stages were accomplished in exactly one of these properties.

\section{Definition of sample collection sites}

The collections of water and O. niloticus fillet samples occurred on four different occasions, corresponding to the four seasons of the year: i) April 2010 (autumn); ii) August 2010 (winter); iii) November 2010 (spring) and iv) March 2011 (summer).

The water sample collection points on each of the properties were selected according to the characteristics of each fish farm. On the property responsible for the production of fingerlings, water samples from the cages maintained in hothouses and from the stream supplying such tanks at two distinct points were also collected. The first took place before the supply to the cages, and the second at the outflow point of them. On all properties, collections from juvenile fattening tanks, as well as from the stream feeding these tanks were accomplished. On the property responsible for fish slaughtering, water samples were also collected from the debugging tanks and from the slaughterhouse. In this same fish farm, collections of fillet of $O$. niloticus directly from the slaughterhouse refrigerator were conducted.

In the fish culture stations with net cages, the cages were arranged in rows, and fish separated by size and stage of development. Water samples were collected from tanks containing fish in three different development stages: juvenile, intermediate and adult. Collections of water samples from two different locations of installation of net cages were also performed: i) between the riverbank and the cages and ii) between the riverbed and the cages.

\section{Sampling collection}

For the collection of water samples, $50 \mathrm{ml}$ sterilized polypropylene bottles $\left(121^{\circ} \mathrm{C}, 20\right.$ minutes) were kept sealed until the time of use. Each bottle was submerged until its upper part reached the depth of about five centimeters, when the bottle cap was removed. Each bottle was identified according to the collection point and the samples were immediately stored in isothermal boxes containing ice and protected from light. All tests were performed within a maximum of four hours after collection of the samples. Water temperature of the tanks was recorded at $30 \mathrm{~cm}$ depth.

For the study of the fillets in each season of the year, three samples, each consisting of three fillets, which were collected just after slaughter. These samples were stored in trays sealed with plastic film and transported to the laboratory in isothermal boxes at $10^{\circ} \mathrm{C}$ and protected from light. All samples were performed under the same conditions and the analyses not exceeding a maximum of four hours after collection.

\section{Research of microorganisms}

The assessment of indicator microorganisms was conducted both from water and tilapia fillets samples employing a ready-to-use method, commercially available (Petrifilm, 3M Brazil Ltda), following the instructions of the manufacturer regarding the procedures of inoculation, incubation of the samples and reading of the results. For this purpose, the volume of $1 \mathrm{ml}$ of each sample of sterile water was used for the preparation of serial decimal dilutions. The fillet samples were analyzed using $25 \mathrm{~g}$ diluted in $225 \mathrm{~mL}$ of $1 \%$ peptone water, homogenized in Stomacher (ITR, Brazil) for $3 \mathrm{~min}$ and followed by serial decimal dilutions thereafter. Further, both dilutions of water and fillet samples were plated on Petrifilm AC plates for the enumeration of mesophilic aerobes (AB) and on Petrifilm EC plates for the enumeration of total coliforms (TC) and Escherichia coli (EC). The results of the counts were corrected according to the dilutions accomplished and expressed in $\mathrm{CFU} / \mathrm{ml}$ for $\mathrm{AB}$ and $\mathrm{CFU} / \mathrm{ml} 100$ for $\mathrm{TC}$ and E. coli.

\section{Statistical approach}

The models for the $\mathrm{AB}, \mathrm{TC}$ or EC response variables comply with the formulation

$\log (\mathrm{C}) \sim$ Weather Station * Tank

where " $\mathrm{C}$ " denotes the observed count (AB, TC or EC) in each water sample; the weather station has numeric values: 1 for winter, 2 for spring, 3 for fall and 4 for summer; and "tank" refers to the type of tank, a nominal variable with two possible values: ponds or net cages, the first being the reference value (baseline).

To analyze the influence of predictor variables (weather station and type of tank) on bacterial counts (AB, TC and EC) and the possibility of interaction between two predictors, the R software, version 2.14.0, and in particular the MASS package was used for adjusting generalized linear models with negative binomial distribution, due to the high dispersion of data. In this model, the coefficient of each predictor variable was evaluated, as well as the coefficient of the interaction between the predictor variables and their significances. The 5\% descriptive level is used as cut-off value to establish the significance of each coefficient.

A linear regression between the temperature data from the water samples collected in the growing tanks for the juvenile, pre-juvenile, intermediate, fattening and purification stages in the four seasons (autumn, winter, spring and summer) was elaborated to justify considering season as a numerical discrete variable with values from 1 to 4 . Thus, the factor underlying the influence of the season that effectively denotes the significance of the model coefficients is in fact the effect of temperature on bacterial counts.

\section{Results}

The variables used were "weather station", "source", "stage", "tank" and bacterial counts. The characteristics of all variables have already been explained above, except for the variable "source", which indicates the source of water for breeding fish, comprising a total of 18 diverse categories, including stream, tap, bank and riverbed. Unquestionably due to such diversity, this variable could not be used as a predictor, but the data from these sources were used to help interpret the results of the other variables. "Stage" denotes the development phase of the fish, a categorical variable with the following values: larval, pre-juvenile, juvenile, intermediate, fattening, debugging and filleting. At the larval 
stage, there is control of temperature, and therefore the variable weather station has NA (not available) value at this stage of the production chain.

For the variable tank, there were 24 observations in the ponds and 72 in net cages, besides 32 observations categorized as NA, because they cannot be categorized in one way or another. In the variable weather station, there were 12 cases listed as NA because they were in the larval stage. The analysis was performed on 128 samples collected for each of the three types of bacteria, in the four seasons of the year, in five fish farmers, with 16 missing data for $\mathrm{AB}, 18$ missing data for TC and 44 missing data for EC.

In the Figure 1 is showed the quantification of $\mathrm{AB}, \mathrm{TC}$ and $\mathrm{EC}$ bacteria in water samples collected from tanks representative of the different stages (larval, pre-juvenile, juvenile, intermediate, fattening, debugging and filleting) along the production chain of $O$. niloticus in northern Paraná State, Brazil. The quantification of $\mathrm{AB}$ bacteria presented a median value of $10^{4} \mathrm{CFU} / \mathrm{ml}$ at all stages of the production chain. As for the TC bacteria, samples from most of the production chain stages showed a median of $10^{3} \mathrm{CFU} / 100 \mathrm{ml}$, except for the debugging and filleting stages, which presented a median of $10^{4} \mathrm{CFU} / 100 \mathrm{ml}$. The quantification of EC at the different stages of the production chain showed greater variation in median values than the quantification of $\mathrm{AB}$ and TC bacteria. The stages of larval, juvenile, intermediate and fattening showed a median of $1 \mathrm{CFU} / 100 \mathrm{ml}$ and the detection of these bacteria in a few isolated samples in these steps (as evidenced by the isolated points on the graphs), while the other stages of development (slaughter, pre -juvenile and debugging) showed medians of 200 $\mathrm{CFU} / 100 \mathrm{~mL}^{-1}, 800 \mathrm{CFU} / 100 \mathrm{~mL}^{-1}$ and $10^{4} \mathrm{CFU} / 100 \mathrm{~mL}^{-1}$, respectively.
Figure 2 displays the quantification of $\mathrm{AB}, \mathrm{TC}$ and $\mathrm{EC}$ bacteria in the water samples of $O$. niloticus growing tanks, as well as the comparison between the two tank types analyzed, i.e., net cages or ponds. In this Figure, only the pre-juvenile, juvenile, intermediate and fattening stages were included. The quantification of $\mathrm{AB}$ bacteria generated a median of about $10^{4} \mathrm{CFU} / 100 \mathrm{~mL}^{-1}$ for both types of tank, while the number of TC bacteria generated a median of $10^{3} \mathrm{CFU} / 100 \mathrm{~mL}^{-1}$ for both types of tank, and the EC showed a median of $1 \mathrm{CFU} / 100 \mathrm{~mL}^{-1}$ for both types of tank. However, the samples of ponds presented a greater degree of data dispersion (as evidenced by the height of the column on the graph) than the samples from the netcages.

Figure 3 shows the quantification of $\mathrm{AB}, \mathrm{TC}$ and $\mathrm{EC}$ bacteria in the water samples of $O$. niloticus growing tanks and also the results obtained in the four weather seasons of the year, ranging from April 2010 to March 2011, throughout the entire production chain, with the exception of the larval rearing stage. The quantification of $\mathrm{AB}$ and $\mathrm{TC}$ bacteria generated medians around $10^{4} \mathrm{CFU} / \mathrm{m} \mathrm{L}^{-1}$ and $10^{3} \mathrm{CFU} / 100 \mathrm{~m}$ $\mathrm{L}^{-1}$, respectively, for the four sampling periods. The quantification of EC in the winter and spring seasons generated a median of $1 \mathrm{CFU} / 100 \mathrm{~m}$ $\mathrm{L}^{-1}$, while in the autumn, the median was around $400 \mathrm{CFU} / 100 \mathrm{~m} \mathrm{~L}^{-1}$. No observations were made for EC in the summer.

In the Figure 4 are showed the temperature data from water samples collected from the tanks for the juvenile, pre-juvenile, intermediate, fattening and debugging stages in the four climate seasons evaluated. The average winter temperature was $20^{\circ} \mathrm{C}$, followed by spring and fall, with $24^{\circ} \mathrm{C}$, and summer with $28^{\circ} \mathrm{C}$. The linear regression analysis, $\mathrm{T}$ $\sim$ Station, presented a coefficient of 1.77 and p-value of $3.2 \times 10^{-5}$,
A

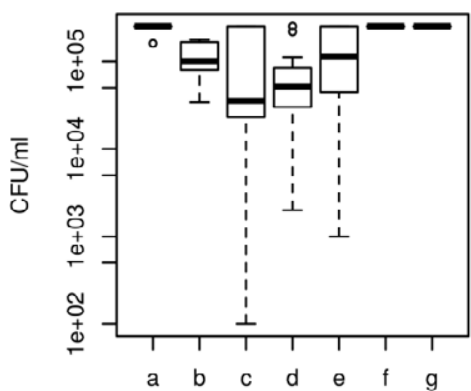

B

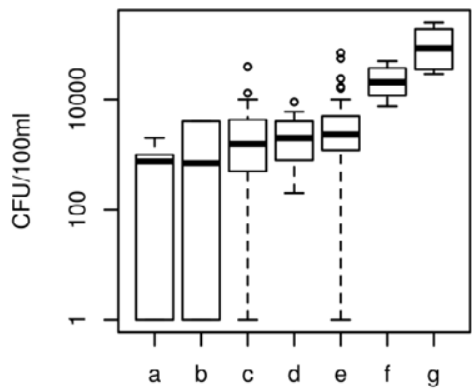

c

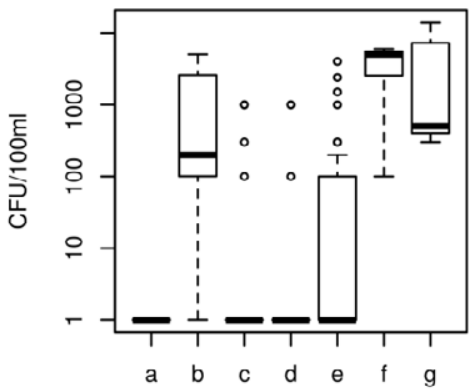

Figure 1: Box plots for counts of aerobic bacteria (A), total coliform (B) and Escherichia coli (C) in water samples collected from tanks of different stages along the production chain of Nile tilapia; a: larval, b: pre-juvenile, c: juvenile, d: intermediate, e: fattening, f: debugging, g: filleting.

A

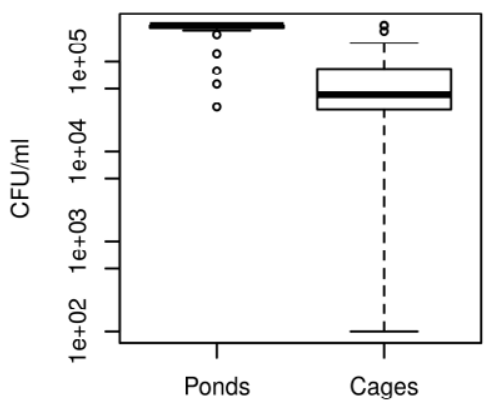

B

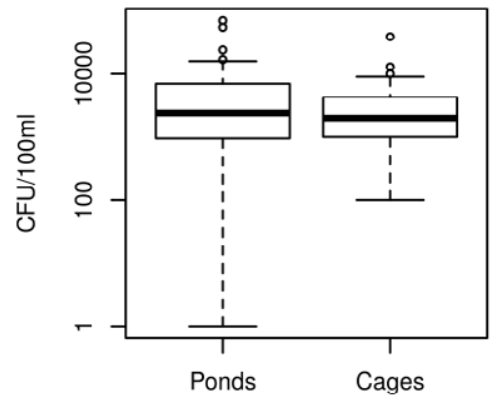

C

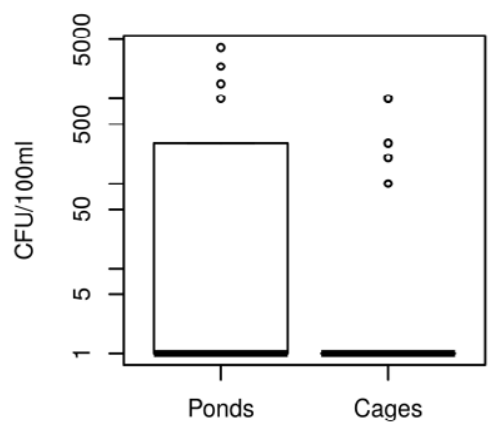

Figure 2: Box plots for counts of aerobic bacteria (A), total coliform (B) and Escherichia coli (C) in water samples collected from different tank types (net cages or ponds) of the production chain of Nile tilapia. 
A

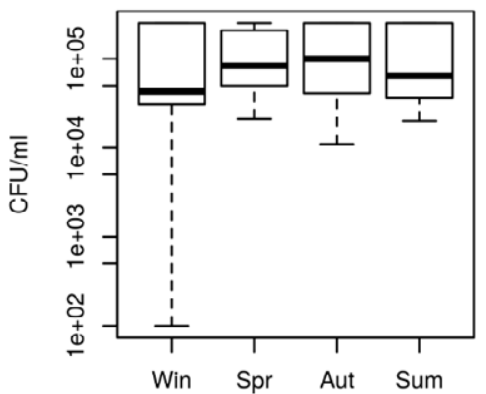

B

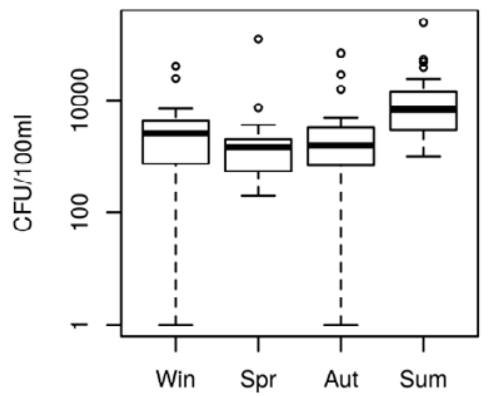

C

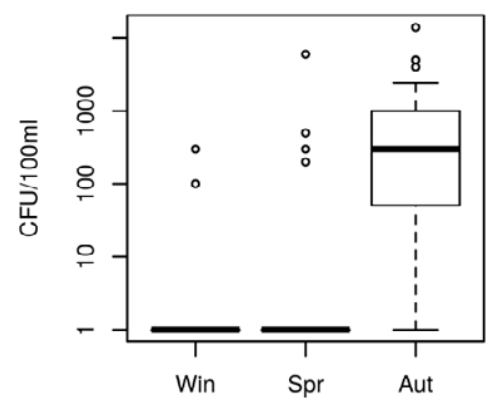

Figure 3: Box plots for counts of aerobic bacteria (A), total coliform (B) and Escherichia coli (C) in water samples collected from tanks (net cages or ponds) of the production chain of Nile tilapia along seasons between April 2010 and March 2011.

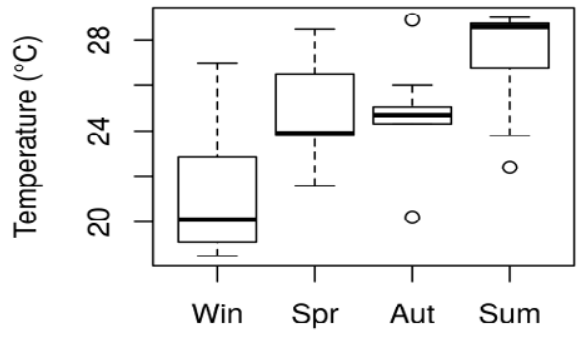

Figure 4: Box plots of water temperatures (30 cm depth) from production chain of Nile tilapia collected along seasons between April 2010 and March 2011.

\begin{tabular}{|l|c|c|c|c|c|c|}
\hline Variable & \multicolumn{2}{|c|}{ AB } & \multicolumn{2}{c|}{ TC } & \multicolumn{2}{c|}{ EC } \\
\cline { 2 - 7 } & Coefficient & P-value & Coefficiente & P-value & Coefficiente & P-value \\
\hline Intercept & $1.83 e 5$ & $<2 \mathrm{e}-16$ & $5.92 \mathrm{e} 2$ & $<2 \mathrm{e}-16$ & 0.34 & 0.15 \\
\hline Season & 1.1 & 0.66 & 2.48 & $5.8 \mathrm{e}-6$ & 8.88 & $1.6 \mathrm{e}-15$ \\
\hline Tank & 0.29 & 0.011 & 2.39 & 0.17 & 0.19 & 0.065 \\
\hline Season*tank & 1.0 & 0.87 & 0.56 & 0.012 & 0.91 & 0.78 \\
\hline
\end{tabular}

Table 1: Coefficients and significance level of the significant variables applying the negative binomial model for the quantification analysis of $A B, T C$ and $E C$ bacteria throughout the $O$. niloticus production chain.

evidencing significant differences between the recorded temperatures in winter and summer, and between the temperatures recorded in spring and summer. However, the temperatures recorded in fall showed no significant differences from the temperatures recorded in spring and summer. This analysis justifies the use of the variable Station as a discrete variable.

Table 1 shows a summary of the models adjusted for counting bacteria in the water samples analyzed during the period from April 2010 to March 2011 throughout the tilapia production chain. For each bacterial category analyzed (AB, TC or EC) coefficients and their respective significance levels ( $\mathrm{p}$-values) are presented. The significant coefficients with values greater than 1.0 (significance with value equal to or lower than 0.05 or $5 \%$ ) substantially influence the increase in bacterial count in relation to the base line, whereas significant coefficients with values lower than 1.0 influence the reduction in the bacterial count, also in relation to the baseline.

The results presented in Table 1 show that the weather season positively and significantly influenced the TC and EC bacterial count, which presented coefficients of 2.48 and 8.88 , respectively, and were significant $\left(5.8 \times 10^{-6}\right.$ to $1.6 \times 10^{-15}$, respectively). However, this variable did not exert a significant influence on the count of the $A B$ bacteria. The TC bacteria exhibit a tendency to increasing counts according to the weather station, and were ordered according to the average temperatures observed, with the lowest counts observed in samples collected in the winter, and the highest counts in samples collected in the summer. For EC, the ordering of the seasons was similar, with the lowest counts obtained in samples collected in the winter, followed by samples collected in the spring and fall. No samples were collected in the summer.

When the data were analyzed in relation to the type of tank used for raising tilapia, i.e., net cages or ponds, one can see that the type of tank is a factor that influences the count of the three categories of bacteria evaluated (AB, TC and EC). The data in Table 1 show that the count of $\mathrm{AB}$ bacteria is significantly lower in the net cages than in the ponds, presenting a coefficient of 0.29 and p-value of $1.1 \%$. This behavior repeats in the counting of EC, which presented a coefficient of 0.19 , but with marginal significance $(6.5 \%)$. The interaction term was not significant for both $\mathrm{AB}$ and $\mathrm{EC}$ counts. For TC, the direct influence of the tank was not significant (p-value 0.17). Nevertheless, the significance of the interaction term indicated that the growth effect throughout the seasons on this bacterial count is attenuated in net cages by a factor of 0.56 , i.e., the growth is $44 \%$ lower compared to the variation in temperature throughout the seasons. The interaction effect shows significance of $1.2 \%$.

The determination of the presence of AB, TC and EC bacteria in fillets of tilapia collected from the slaughterhouse was done immediately after slaughter of the animals. The data were analyzed aiming to verify the influence of the climate season, since the tank variable has no meaning at the slaughter stage. There were 12 repetitions, three for each season of the year. The data in Figure 5 show that the $\mathrm{AB}$ bacteria count ranged from $10^{3}-10^{5} \mathrm{CFU} / \mathrm{g}^{-1}$ of fillet, while the TC bacteria count ranged from 500 to $10^{4} \mathrm{CFU} / \mathrm{g}^{-1}$, according to the season evaluated. Additionally, the count of EC was always less than $10 \mathrm{CFU} / \mathrm{g}^{-1}$. Data analysis applying the negative binomial model allowed the classification of the weather station as a predictor variable with a significant influence on the $A B$ bacterial count in fillets, with coefficient of 1.8 and significance of $3 \%$. Likewise, the weather station influenced the TC bacteria count in fillets, showing a coefficient of 4.4 and significance lower than $0.1 \%$ ( $\mathrm{p}$-value $\left.<2 \times 10^{-16}\right)$. 
A

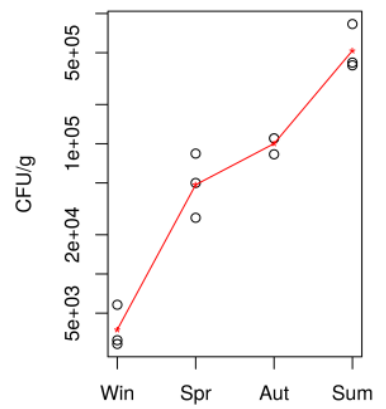

B

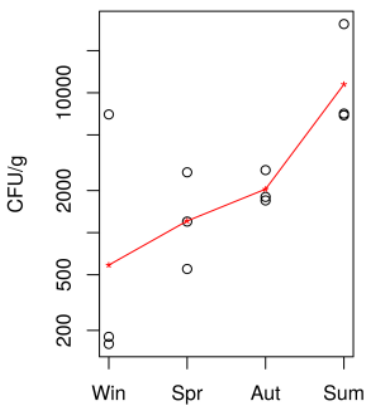

Figure 5: Count of aerobic bacteria (A) and total coliform (B) in fillets of Nile tilapia collected along seasons between April 2010 and March 2011.

\section{Discussion}

The water quality is one of the main factors that directly influence the productivity and health of farmed fish in net cages or ponds. There are several water parameters that must be taken into consideration in the growth of fish, including physical parameters such as temperature, color and turbidity; chemical parameters, such as $\mathrm{pH}$, dissolved oxygen, amount of ammonia and nitrite; and microbiological parameters, which include the quantification of different bacterial groups. Therefore, one must consider water as a potential source of contamination of fish and derived products, especially microbiological contamination [14].

The count of $\mathrm{AB}$ bacteria was assessed at all stages of the Nile tilapia production chain of Figure 1A. These bacteria act on the decomposition of nutrients, producing part of the food consumed by other small organisms that live in the waters of lakes and rivers, being the base of the food chain. In Brazil, there is no legislation determining the minimum or maximum amount of bacteria in fish farming waters, thus, our results were compared to those obtained by other authors, and were lower than the scores obtained by $[3,7]$ and higher than those reported by [15] in tilapia culture ponds.

Regarding counts of TC and EC in the water samples, the highest values were obtained in the debugging and filleting stages. In Brazil, there are no specific regulations concerning the presence of bacteria in the waters at these stages. However, the presence of these bacteria indicates the contamination of the environment, since they are not part of the fish microbiota, but of warm-blooded animals, including humans [16]. Previous studies [4,5] showed the importance of monitoring the presence of coliforms in the fish farming waters, including the culture of Nile tilapia, since these authors detected the presence of these contaminants in the organs of fish grown in waters with the presence of these bacteria [17] experimentally inoculated $E$. coli in the water tank and recovered the bacteria from the fish muscle.

The comparison between the two types of tank, as shown in Table 1 , indicates that the bacteria counts in net cages were significantly smaller than those obtained from the ponds. Similar results were also found for EC, but with marginal significance (6.5\%), indicating that further studies should be conducted to evaluate the importance of the type of tank in the count of EC. Regarding TC bacteria, the estimates showed in Table 1 permits the identification of the climate station as a variable that significantly influenced the increase in the count of these bacterial groups in both types of tanks, since the analysis of the data demonstrated a tendency to increase in TC bacterial count according to the average temperatures observed in water samples collected in the different climate seasons. It was also observed that this increase is more pronounced in ponds.

The results in Table 1 show that net cages had lower AB and EC bacterial counts throughout the year compared to ponds and, therefore, respond differently to environmental alterations resulting from changes in the climate seasons. Among the factors that may contribute to the increase in bacterial counts of ponds, is the dilution factor, i.e., after the occurrence of the summer rainy season, which may carry contaminants from the neighborhood to the water bodies of both types of tank, the incidence of the dilution factor is smaller in ponds compared to net cages.

During the assessment of samples of tilapia fillet, increased $A B$ and TC bacterial counts were found in combination with the increase in temperature. Considering that the count of these bacterial groups in water samples responded to climate changes differently from the count observed in fillets, intrinsic factors of the slaughter and filleting processes are responsible for this increase. The counts of EC in fillets showed a low contamination level of same, regardless of the climate station, being always below the limits recommended by FAO [18]. Thus, in the event of increased temperature, greater attention should be given to the slaughter and filleting processes, aiming to reduce the risk of contamination of fillets.

The joint analysis of the results shows that the highest counts of all bacterial groups assessed were obtained in samples of water at the debugging stage, which precedes the slaughter stage to obtain filet. The application of preventive approaches based on the target of reducing the risk of contamination of fish may curtail the risk of food borne diseases. Thus, the results of this study suggest that additional care must be deployed at this stage, which may result in obtaining fillets with low bacterial counts and, consequently, safer for consumption and with greater shelf life.

\section{Acknowledgments}

This work was supported by Conselho Nacional de Desenvolvimento Científico e Tecnológico (CNPq), Brazil (process 472648/2009-8). We thank to the fish farmers for their participation in this study.

\section{References}

1. Naylor RL, Goldburg RJ, Primavera JH, Kautsky N, Beveridge MCM (2000) Effect of aquaculture on world fish supplies. Nature 405: 1017-1024

2. Naylor RL, Hardy RW, Bureau DP, Chiu A, Elliott M, et al. (2009) Feeding aquaculture in an era of finite resources. Proceedings of the National Academy of Sciences 106: 15103-15110.

3. Gorlach-Lira K, Pacheco C, Carvalho LC, Júnior, HNM, Crispim MC (2013) The influence of fish culture in floating net cages on microbial indicators of water quality. Braz J Biol 73: 457-463.

4. Mandal, SC, Hasan MS, Rahman, Manik ZH, Mandal M, et al. (2009) Coliform Bacteria in Nile Tilapia, Oreochromis niloticus of Shrimp-Gher, Pond and Fish Market. World Journal of Fish and Marine Sciences 1: 160-166.

5. Pal D, Gupta D, Chanchal (1992) Microbial pollution in water and its effect on fish. Journal of Aquatic Animal Health 4: 32-39.

6. Azevedo, PA, Podemski CL, Hesslein RH, Kasian SEM, Findlay DL, et al. (2011) Estimation of waste outputs by a rainbow trout cage farm using a nutritional approach and monitoring of lake water quality. Aquaculture 311: 175-186.

7. Ntengwe FW, Edema MO (2008) Physico-chemical and microbiological characteristics of water for fish production using small ponds. Physics and Chemistry of the Earth 33: 701-707.

8. Degefu F, Mengistu S, Schagerl M ( 2011) Influence of fish cage farming on water quality and plankton in fish ponds: A case study in the Rift Valley and North Shoa reservoirs, Ethiopia. Aquaculture 316: 129-135.

9. Schenone NF, Vackova L, Cirelli AF (2011) Fish-farming water quality and 
Citation: Souza GMDD, Pretto-Giordano LG, Vilas-Bôas GT, Carvalho TOD, Silva-Souza AT, et al. (2015) Microbiological Evaluation of Water and Fillets in the Production Chain of Nile Tilapia (Oreochromis niloticus) J Aquac Res Development 6: 344. doi:10.4172/2155-9546.1000344

Page 6 of 6

environmental concerns in Argentina: a regional approach. Aquacult Int 19: 855-863.

10. Plumb JA (1997) Infectious diseases of tilapia

11. Shoemaker CA, Evans JJ, Klesius PH (2000) Density and dose: factors affecting mortality of Streptococcus iniae infected tilapia (Oreochromis niloticus). Aquaculture 188, 229-235.

12. Godfree AF, Kay D, Wyer MD (2003) Fecal streptococci as indicators of fecal contamination in water. Journal Applied of Microbiology 83: 110-119.

13. Al-Harbi AH, Uddin N (2005) Bacterial diversity of tilapia (Oreochromis niloticus) cultured in brackish water in Saudi Arabia. Aquaculture 250: 566-572.

14. Surendraraj A, Farvin KHS, Yathavamoorthi R, Thampuran N (2009) Enteric bacteria associated with farmed freshwater fish and its culture environment in Kerala, India. Research Journal of Microbiology 4: 334-344.

15. Al-Harbi AH, Uddin N ( 2003) Quantitative and qualitative studies on bacteria flora of hybrid tilapia (Oreochromis niloticus $\times$ Oreochromis aureus) cultured in earthen ponds in Saudi Arabia. Aquaculture Research 34: 43-48.

16. Cohen J, Shuval HI ( 1973) Coliform, fecal coliform and fecal streptococci as indicators of water Pollution. Water Soil Pollution 2: 85-95.

17. Guzmán MC, Bistoni ML, Tamagnini LM, González RD (2004) Recovery of Escherichia coli in fresh water fish, Jensynsia multidentata and Bryconamericus iheringi. Water Research 38: 2367-2374.

18. FAO (1979) Manuals of food quality control. FAO Food and Nutrition paper $14 / 4$. 